\title{
The Influence of Process Approach on English as Second Language Students' Performances in Essay Writing
}

\author{
AKINWAMIDE, Timothy Kolade \\ Ekiti State University, Ado Ekiti, Ekiti State, Nigeria \\ E-mail: akinwamidetim@rocketmail.com
}

Received: December 13, 2011

Accepted: February 1, 2012

Published: March 1, 2012

doi:10.5539/elt.v5n3p16

URL: http://dx.doi.org/10.5539/elt.v5n3p16

\begin{abstract}
This study examined the influence of Process Approach on English as second language Students' performances in essay writing. The purpose was to determine how far this current global approach could be of assistance to the writing skill development of these bilingual speakers of English language. The study employed the pre-test post-test control quasi-experimental research design. The sample consisted of 80 senior secondary school final year students. The research material included the senior secondary school English Language recommended textbook, National Examination Council (NECO) and West Africa Examinations Council (WAEC) English Language Syllabi, Federal Ministry of Education English Language Curriculum, English-Language Teachers' Lesson Notes and Students Essay Writing Exercise books. The West African Examinations Council's (WAEC) English Language Essay Question as an adapted instrument was used to gather data. The data generated were subjected to statistical analysis and the results of the analysis showed that there was no significant difference between the pre-test scores of both the Control and the Experimental group which indicated the homogenous state of both Control and Experimental groups. There was significant difference in the post-test scores of the Experimental and the Control groups. There was no significant difference between the pre-test and post-test scores of the students in Control group. As evident from the out-come of the research, the Process Approach (which presents writing in multiple drafts before the final writing) had significant effect on students' overall performance in essay writing.
\end{abstract}

Keywords: Product approach, Process approach, Students' performance, Essay writing, English as a Second Language

\section{Introduction}

English Language can be said to dominate among the four to five thousand languages in the world. It functions in different forms in the different countries and states of the world. It can be the lingua franca, foreign language, second or third language and it may be employed as inter- or intra- national language within a speech community. Kolawole (1991) says the reason for this is not far-fetched because as Western Civilization is taking over the whole world, so also is English Language existing in congruent to Western Civilization.

One striking fact about this global importance of English Language is that, using English has nothing to do with one's nationality or with the initial fact of the spread of English-speaking colonies. The Peruvian air Pilot from a country relatively untouched by past British or American expansions needs English for his Job, so also the Polish doctor, working for the world Health Organization (WHO) in tropical countries. In the world, that has become a global village, and in Nigeria a country in the world, a former colony of Britain, English has become a language of everyone.

It is right from this perspective that one weighs the importance of English Language. English got to Nigeria as far back as the $15^{\text {th }}$ century through Europeans who came to trade, explore, Christianize and colonize Black Africans Nigeria inclusive. It later found its way into our educational system and subsequently became the language of administration, commerce, law, politics and education.

The multi-lingual and multi-ethic stratifications of Nigeria favor the adoption of English as the official language and so is employed as inter- / intra- national language in Nigeria. To enhance the development of English language in the country and to help Nigerians to gain international acceptability, English is being used in schools, colleges, polytechnics and Universities in Nigeria. It is an important core subject in the school curriculum.

The West African Examinations Council (WAEC) and the National Examination Council (NECO) are the examining-bodies responsible for the examination of English Language at the secondary school level in Nigeria. The 
English Language paper is classified into the following groups: Comprehension and Summary, Lexis and Structure (Objective) and the Continuous Writing Paper. The Continuous Writing aspect which is the focus of this work is graded by the examination bodies by using the analytical grading system.

$\begin{array}{lll}\text { Content } & = & 10 \text { marks } \\ \text { Organization } & = & 10 \text { marks } \\ \text { Expression } & = & 20 \text { marks } \\ \text { Mechanics } & = & 10 \text { marks }\end{array}$

(WAEC \& NECO)

Students need a credit pass in this subject before they can secure admission to any tertiary institution. The yearly performances of the students have become worrisome to all and sundry. In order to pass this subject, some employ antisocial ways of passing the English Language paper. This portends danger to a country that wants to achieve international recognition and that wishes to achieve lofty objectives using education as a working tool. Nigeria like any other nation that craves for development cannot afford to fall among the bad users of English Language; therefore, the government has been trying all means to ensure improvement in the performances of the students.

Obemeata (1995) says deficiency in English language is a major problem of Nigerian educational system and it is not of recent origin. It is a fact that teaching and learning English Language as a second language may not be an easy task for the following reasons:

$>\quad$ other languages have been there before the introduction of English Language. Every language is embedded in a particular culture and English Language is from a culture which is foreign to the Nigerian learners and teachers.

$>\quad$ Second language teachers' of English language have their own limitations. (Akinwamide, 2007)

$>\quad$ moreover, the situation becomes more arduous when one looks at the teaching and learning of the four basic skills of language, listening, speaking, reading and writing. The first two skills, listening, and speaking, come naturally in the growing child but conscious effort must be made to teach and learn how to read and write.

It is a fact that not everyone who reads can write hence, the writing skill has been seen as the most complex skill among others. The absurdity of essay writing scenario in Nigerian secondary schools is further aggravated with the stated objectives in the syllabi and what actually goes on in the essay-writing classroom coupled with widow dressing approach given to the objectives by the textbook authors. For instance, the national Examination council syllabus (NECO 2004/06, page 104) states, "The objective of the essay writing section is to test candidates' ability to communicate effectively in writing. The kinds of writing demanded are: "Narrative, Description, Argumentative, /Debate, Exposition, Letter, Article, Speech, Report, and Creative Writing".

(NECO 2004 / 06, pg 104) The textbooks which the teachers are using for the teaching of essay writing do not adequately pursue the stated objectives. The Product Approach to the teaching of essay writing which the English language teachers are using makes the teachers to overtly depend on the textbooks. Vanessa (2004) opines that, guided or controlled method (from Product Approach) does not allow students to write independently. Therefore, this research sought to see how the Process Approach, which gives independent frame of mind to writers to write, based on experience, and imagination could -

help the students to satisfy the requirements of both the examination and teaching syllabuses, around for a rewarding academic life.

\section{Theoretical Framework}

Language learning is sandwiched between two basic theories which act as the springboard of how and why language is learnt. Whatever approach or method that may come up sprang from the Behaviorist and Mentalist theories of language learning. On the global perspective, every other approach can be traced to these theories.

The skill of writing had been subjected to many theories in the bid to develop the skill of writing in the students. Proet and Gill (1986) itemized the earlier theories on how students learn to write as follows:
(a) The Theory of Frequency
(b) The Grammatical Theory
(c) Error Correction Theory 
(d) The Building Blocks Theory

(a) The Theory of Frequency: This theory recognizes frequent practices on writing as essential to writing mastery even when the writer is not monitored. Nevertheless, research has shown that frequency alone may not sustain development in writing.

(b) The Grammatical Theory of learning to write according to Proett,-et el (1986) is built on the hypothesis that knowledge of structures and the rules for combining them will result in students becoming writers. Yet, Oden (1999) says research on writing has however revealed that this teaching of grammatical structures has not improved the writing skill of students.

(c) Error correction theory believes in correction of student's error as a step towards making them writers. Yet classroom experiences show that incessant corrections frustrate students as well as bore teachers. Earlier researches on writing have however failed to establish correlation between correction and improvement in students' writing ability.

(d) The building blocks theory is premised on the notion that students learn to write through smaller units known as building blocks (Proett et al 1986). This theory focuses more on form than the actual substance of writing. Learning of sentences, paragraphs, clauses and other mechanics may not address the conceptual form in writing skill.

\section{Statement of the Problem}

There had been many complaints on the poor performances of students in the Essay Writing paper at the senior secondary school level as evident in the work of Kolawole (1998), Odeh (2000) and A (2008). Analysis of WAEC and NECO (2007) results support this long time discovery. Okedara and Odeh (2002) opined that over the years, the problem of poor writing skill has persisted and that this revealed that the traditional method of teaching writing (product approach) was ineffective. Hence, this current prevailing circumstance and the different opinions on the nature of writing make investigation into ways of developing the writing skill for better performances inevitable.

Oluwadiya (1992) in her research work came out with a disquieting discovery: She says many teachers in Nigeria are not aware of the shift from the traditional writing approach (the product- approach) to the Process-oriented Approach. The researcher, therefore, carried out a scholastic review of the current texts in circulation at the secondary school levels in Ekiti and Ondo States, it was discovered that, the authors of the recommended textbooks feature the product approach in their English Language textbooks in circulation and English Language teachers have been employing the Product approach to teach the students essay writing. The Product- approach was dropped four decades ago because of its inability to meet the global demand for writing [Montague 1995]. Therefore, the researcher employed the Process Approach to observe its effects on the writing skill development of the students.

\section{Purpose of the Study}

This study investigated the influence of process approach on English as second language students' performances in essay writing. Specifically, the purpose was to examine the plausible influence this writing approach would have on second language writing skill development. Awareness of this among language teachers may assist the language teachers in the teaching of Essay Writing for better performance.

\section{Research Questions}

The following research questions were raised based on the statement of the problems:

$>$ Would there be any difference between the pre-test scores of students in the Control and Experimental groups?

$>$ Would there be any difference in post-test scores of the students in the Control and Experimental groups?

$>$ Would treatment have any effect on the total performance in writing?

$>$ Would there be any difference between the pre-test and post-test scores of the students in the Experimental group?

$>$ Would there be any difference between the pre-test and post-test scores of the students in the Control group?

\section{Research Hypotheses}

In order to answer the questions raised on this study, the following null-hypotheses were tested at 0.05 level of significance.

$\mathrm{HO}_{1}$ There would be no significant difference between the pre-test scores of the students in the Control and Experimental groups.

$\mathrm{HO}_{2}$ There would be no significant difference in the post-test scores of the students in the Control and Experimental groups. 
$\mathrm{HO}_{3}$ Treatment would have no significant effect on total performance in essay writing.

$\mathrm{HO}_{4}$ There would be no significant difference between the Pre-test and Post-test scores of the students in the Experimental group.

$\mathrm{HO}_{5}$ There would be no significant difference between the Pre-test and Post-test scores of the students in the Control group.

\section{Scope of the Study}

The study covered two states in the southwestern part of Nigeria. The states are Ekiti and Ondo. The predominant Language in these states is Yoruba Language which is one of the three major languages spoken in Nigeria. All the students have English as a second language. The students were all in boarding house, which guaranteed their appropriateness for experimentation. The sampled schools are in the respective state capitals. The two schools had been presenting students for final examinations for more than two decades. The English-Language teachers from the two schools used the same English Language textbook (Intensive Eng/ish by Benson. O. Oluikpe, Nnaemeka B. Anasiudu, Emeka J. Otagburuaggu, Elsie A. Ogbonna and Sam Onuigbo).

\section{Review of Related Literature}

1. Factors Militating Against Second Language Acquisition

2. The Teaching and Nature of Writing

3. Juxtaposition of the Basic Approaches -Product and Process

4. Composition Writing in English Language by Second Language Learners.

\subsection{Factors Militating Against Second Language Acquisition}

Any second language, no matter its acceptability and popularity is a new language to the intending learner(s). Hence, that it is new does not make its newness the only factor that affects the acquisition of the language but there are other factors. Language acquisition is dependent on a few numbers of notions. This includes the notion of a critical period in language development which refers to the period when the human organism is said to be sensitive specifically to a definite aspect of language acquisition. This means that certain periods are naturally slated for the development of each of the language component, namely; phonological part, syntactic part, morphological part, semantics and pragmatics parts.

Researches in psycholinguistic have revealed that the difficult periods of child's development seem to go along with Piaget's theory of cognitive development stages. Piaget in his discovery said, "there is a period of growth spurt between two and four years of age; this is the sensitive period for phonological development" We are to understand that the particular period, which is marked for development of componential part of language does not terminate further development in language acquisition, rather the period is sensitive to the development of a particular language development. In addition, the following other factors affect child's sensitivity to new language development:
(a) Neurophysiology
(b) Psychology
(c) Environments.

Neuro-physiological theory addresses the lateralization of the brain. There is the claim that language cannot be learnt easily after the completion of brain laterization, which is associated with puberty; at another perspective, lateralization is said to be completed by age 5 or earlier than age 5. Other still classify lateralization with Piaget's concept of the sensor motor stage. From these, there is a relationship between the sensor motor period and the critical period in language development; hence, the earlier a second language is learnt, the better.

Psychological factor: the psychological composition of an individual is another important determinant in acquisition and performance in language. This is broken down to cognitive, intellectual functioning experience, attitude, motivation and cultural factors. How aptly to reason and engage in intellectual activities, what gears the learner towards acquisition and the importance of the knowledge of such language in the society is addressed under this.

Environmental factors like auditory input, stimulation, semantic input and syntactic output for example, if an individual manifests high degree of learning retardation as a result of certain environmental factors, learning a new language becomes an herculean task. Moreover, the cultural aspect may hinder or enhance learning. For example, in some cultures, parents - especially mothers are said to talk to their female children very constantly. Female children under such a culture perform better linguistically than their male counterparts. 


\subsection{The Teaching and Nature of Writing}

Oluikpe (1979) says writing is a skill, which demands that students plan and organize their imagination clearly and in sequential order to fulfill the essence of writing. Composition teaching and writing is more difficult than teaching and practicing other language skills. This is in agreement with the views of Bell and Burnaby (1984) that writing is an extremely complex cognitive activity in which the writer is required to demonstrate control of a number of variables simultaneously. By implication, it means the writer must plan the content, format, sentence structure, vocabulary, punctuation, spelling and formation of ideas.

White (1981) in Nunan (2000) expresses his view that "Writing is not a natural activity. All physically and mentally normal people learn to speak a language. Yet all people have to be taught how to write". It is right from this perspective that the teaching and learning of writing should be organized and accompanied with concerted effort of the language teacher and careful approach of the students.

Complexity also arises in language teaching according to Lado (1983) highlighting the variations among language teachers with regard to their qualifications and the time allotted to the teaching of any of the macro skills. He says further that the teacher may speak the language natively or he may have studied it on second language basis. It is therefore obvious that some teachers may either gloss over or ignore certain basic skills they find problematic themselves in the teaching processes. Kolawole (1998) says the technical nature of writing and the need to use writing to express a writer's thought in a logical and coherent manner call for it to be taught well. All the other macro-skills of language are taught without facing serious challenges on how to coordinate ideas, thoughts and the application of the mechanics as it is required in writing skill.

\subsection{The Basic Approaches to the Teaching of Writing}

Good plans must be made by the teacher so that the writing class does not become a source of frustration to both students and teachers. The students are confronted with what is expected of them by conventions of written English to express themselves at a far more precise level of grammatical accuracy and rhetorical organization and so if care is not taken, they become confused and bored with composition writing. This is why the teacher must decide which approach he must employ to get the students along. The first popular approach in the teaching of writing is the traditional product-oriented approach.

The Product Oriented Approach: This is also known as 'Models Approach'. This approach focuses on the product the written text that serves as the model for the learner. It was believed that if a model text written by an accomplished and competent writer is given to students to read, the students imbibe all the good qualities of writing and thus become good writers. This approach emphasizes students' exposure to written sentences and paragraphs whether emphasizing grammatical roles or rhetorical patterns.

The Product approach focuses the written text, which serves as a model for the learner; this is where it derived the name 'the model approach'. The proponents of the Product Approach hold the belief that students can learn how to write with minimal error when they are given the composition of a good writer to study before embarking on their own writing. Nunan (1999) says the product approach focuses on writing tasks in which the learner copies and transforms from teacher supplied models. Adams (2006) sees the product approach following a linear pattern. This is what Bruton (2005) describes as single-draft think -plan linear procedures with once -off correction grounded on product models of writing. The primary goal of this approach is an error -free coherent text.

In this approach, students would be given writing exercises that would reinforce language structure that they have learned through the imitation and manipulation of grammatical patterns. Examples of such writing tasks are shown in controlled compositions in which students would be given a paragraph and asked to perform substitutions, expansions or completion exercises.

The Process-Oriented Approach: The Process Oriented Approach came into being because of the inadequacies of the model approach. Oluwadiya (1992) says scholars like (Kuhn 1970, Emig 1971, Perl 1979, Hayes and Flower 1980, Graves 1982 and Flower 1985) sought to find out how competent writers write so that the kind of the thinking that precedes such writers' writing can be determined and then taught to the student writers. The research question that prompted these investigations was: "How does the competent writer write?" The finding came forth that, writing is a non-linear, recursive and generative process which involves the following stages viz - pre-writing, composing/writing and re-writing stages. Here, students enjoy procedural information from the teacher before the actual final writing is done. Writing presentations are done in logical sequential order. The pre-writing and the drafting stages afford the students the opportunity of composing their own composition. Figure 1 is a model of the Process Approach by the author

The ordering of the three basic stages in the model above shows that writing is a process which involves several 
identifiable stages like, Prewriting, Writing and the Final draft.

Prewriting: This technique according to Richard and Roland (1995) helps students assess the dimensions of a rhetorical problem and plan its solution. It triggers perceptual and conceptual processes; permitting writers to recall experiences, breakthrough stereotyped thinking, examine relationships between ideas, assess the expectations of their audience, find an implicit order in their subject matter and discover how they feel about the work. Pre- writing can be seen as any writing task that exposes students to self-assessment, observations and exploration of the world around the subject matter. The following are some of the writing tasks under pre-writing:
a. Observation
b. Imagining
c. Clustering
d. Outlining
e. Interviewing
f. Brainstorming

The focus here is developing and ordering of relevant facts. The next stage is composing. Composing. The major task here is putting a draft version on paper. This may feature free-writing or collaborative work. The writer uses the data got through the pre-writing stage as a springboard. The emphasis is on content and organization here. Checking of forms, time and tense relations. Choice of language and focusing the right audience. This is followed by the final write-up. Revision and reviewing of the work is carried out by the writer and peers. Editing is systematically carried out at every stage of the work. Errors are expected in Process Approach. However, the recursive nature of editing at every stage makes the errors to terminate at the editing stage which comes up at the end of each basic stage.

Process approach according to Pica (1986) focuses on the writer's potential for self-correction as a means of achieving success in writing. It places on the students the task of revision at the expense of imitation of perfect work of experts. This is in harmony with the view of the proponents of Process Approach that, want teachers to give their students opportunities to plan, review, clarify and re-organize what they (students) have written on their own.

In the teaching and development of students to become competent writers, teachers of language often select and use writing tasks in language textbooks as the major teaching source. Kwah (1999) says textbook writers are influenced by theoretical developments in writing pedagogy when developing writing tasks. Anthony (2005) says process writing assumes production tasks that prompt self-expression to motivate students as the principal engine for developing second language proficiency in the language classroom. To him, the core activity in process writing is the multiple-draft open-ended writing task. This goes a long way in developing ability to generate ideas. Kapler (1991) summarizes process writing as a vehicle for the discovery and communication of meaning.

\section{Methodology}

Here we have the research design and the statistical procedure employed in carrying out the study. Specifically, the research design, population, sample and sampling technique, research instrument, procedure for data gathering are discussed.

\subsection{Research Design}

The pre-test, post-test, control, two-group-quasi- experimental design was used for this study. This allowed the application of treatment on the experimental group and comparison with the control group.

\subsection{Population}

The population of this study was made up of all the final year students of Ekiti and Ondo States Public Senior Secondary Schools. The two states belong to the Yoruba speaking people of Nigeria. Ekiti State capital city is Ado-Ekiti while Ondo state capital city is Akure. As at the time of this research, Ekiti State had 175 public secondary schools while Ondo state had 285 public secondary schools. All the public schools in both states have been presenting students for the Senior School Certificate Examinations. All the schools used the Federal Ministry of Education English-Language Curriculum. They were also familiar with both NECO and WAEC Syllabi.

\subsection{Sample and Sampling Techniques}

The Sample for this study comprised 80 students selected into the experimental and control groups. Purposive sampling technique was employed to select two states. These are Ekiti and Ondo states. Two schools were purposively selected from Ekiti and Ondo States public secondary schools that were of comparable standards Ado-Grammar School, Ado Ekiti and Christ's Apostolic Church Secondary School, Akure. Ado Ekiti and Akure, the 
locations of the two schools are state capital towns. The two schools had library facility and trained teachers (University graduates of English Language) as English Language teachers. An intact class was purposively selected from the arms of the SS3 classes in these schools. The Experimental school was Ado Grammar School, in Ekiti State and the students were in the boarding house. The Control group was Christ Apostolic Church Secondary school in Akure. The distance between the Experimental group in Ado Ekiti and the Control group in Akure is about 58 kilometers.

\subsection{Research Instrument}

One instrument was used to collect data for this study. The instrument was the Essay Writing Achievement Test (EWAT). This was an adapted WAEC Essay Writing past questions. The test was designed to cover those topics on which the pre-test and post-test observations were based. This instrument is of national and international status and currently in use by the two examination bodies. It has been standardized and is employed by teachers of English for grading School Certificate Examinations and General Certificate Ordinary Level Examinations.

\subsection{Validity of the Instruments}

For face, content analysis and editing, the instruments were given to experts in the field of Measurement and Evaluation, Language Testing Experts as well as the Researcher's Supervisor for critical appraisal before administration. The main instrument is of international standard and so its credibility and validity could be sustained and guaranteed.

\section{Construct Validity}

In ascertaining the construct validity of this instrument, a trial testing of the instrument was carried out on two groups of students and the results compared. A high validity coefficient of 0.93 was obtained.

\subsection{Reliability of Instruments}

The reliability coefficient was established before administration using the test retest method. In doing this, the instrument was personally administered to 80 students on two occasions in Ado Ekiti and after two weeks the same test was administered on the same respondents. The Pearson product moment correlation was used to determine the coefficient (r) 0.93 .

\subsection{Procedure for Data Collection}

The researcher first observed the two groups (Pre-test) after which the experimental group was treated by giving them the Process oriented approach towards writing. The experimental group was taught for six weeks (6 weeks) by the researcher. The students in the control group were not taught by the researcher. The researcher observed all the groups again for post-test. The students' essay work for pre-test and post-test were scored and the result subjected to statistical analysis.

\subsection{Method of Data Analysis}

The data collected were analyzed using descriptive statistics like-arithmetic mean and standard deviation. The researcher employed t-test to compare pre-tests and post-tests of the two groups for all the hypotheses and to test whether there were significant differences between the means.

\subsection{The Hypotheses}

All hypotheses generated were tested with t-test and the decision was taken at 0.05 alpha level of significance.

$\mathrm{HO}_{1}$ : There was no significant difference between the pre-test scores of students in the Control and Experimental groups.

$\mathrm{HO}_{2}$ : There was no significant difference between the post- test scores of the students in the Control and Experimental groups.

$\mathrm{HO}_{3}$ : Treatment has no significant effect on overall performance of the students in the control and experimental groups in essay writing.

$\mathrm{HO}_{4}$ : There was no significance difference between the pre-test and post-test scores of the students in the experimental group.

$\mathrm{HO}_{5}$. There was no significant difference between the pre-test and post-test scores of the students in the control group.

DISCUSSION:

The findings of this study revealed a wide range of different performances as evident in the students' scores. The 
effects of the treatment on the Experimental group sparked off a notable significant difference between the Control and the Experimental groups. At take-off, there was no significant difference between the pre-test scores of the students in the Experimental and Control groups as evident in table one. This displayed the homogeneity of the two groups. This was in line with the general out-cry of the nation about the mass failure recorded yearly in this subject. When the teacher has registered a meaningful impact of a required knowledge scarcely can the students give any worthwhile outputs. The previous results from the schools showed their poor performance which came out in the results of the pre-test.

The students who were taught with the Process-Approach (Experimental group) performed significantly better than those in the Control group. The implication of this was that Process pedagogically empowers students by enabling the students to develop writing and its attendant sub-skills in the course of learning to write. This was corroborated with the view of Gocsik (2005) that the traditional approach (Product Approach) only makes teachers assign topic, grade and hand the paper back to the students. The teachers attend to the product - its form, adherence to rule and correctness - but they don't attend to the writing process.

In the overall performances of the two groups, the treatment applied on the experimental group had a great impact as evident in Table 4. The Process approach which was the treatment given to the experimental class according to (Murray 1980, Sommers 1980, Taylor 1981, Raimes 1985, White 1988, Johnson 1993, Oden 1999 and Okedara et al 2002) is a non-linear, exploratory and generative approach, which permits students to discover and reformulate their ideas as they attempt to appropriate meaning to their work. It recognizes that writing is a systematic act that takes into cognizance some basic activities which bring about a good product.

The importance of the editing stage can not be over emphasized. This allows interventions in students' writings at any stage. Trupe (2001) says effective intervention results in better papers. Students who are asked or required to spend more time on a paper will think more about their topic, retain more information, and develop more powerful insights. Furthermore, students' writing skills need practice in order to perfect the expression. On the other hand, the Control group which was exposed to the conventional approach (the Product Approach), maintained a non-significant variation in the mean scores at pre-test and post-test levels in the test for Expression.

Following the same pattern, the juxtaposition of the pre-test and post-test scores of the Experimental group in all the variables showed that the Process Approach which was the treatment given to the Experimental group formed the basis of the observable changes in the Experimental group. The mean scores at the post-test level are significantly greater than those of the pre-test. Process Approach according to this out-come shows that writing is teachable even in a second language situation.

\section{Conclusion}

From the findings of the study, the Process Oriented Approach was found pedagogically rewarding, revealing and reliable in the development of the writing skill. It is rewarding when students benefit from the contributions of others. Pre-writing and Peer-Editing stages reveal a lot of innate but relevant ideas from the students which may be unknown to the teacher and it is reliable because once the students are able to generate and compose ideas, the ability to write with confidence, inside and outside the school can be guaranteed.

The Process Approach allows errors in the course of writing and re-writing but turns around at the close level of each basic stage to edit. This may explain why Content appropriateness could be ensured, Organization of ideas in logical sequential order could be sustained, grammaticality in Expression could be perfected, and mastering the use and usage of Writing-Mechanics could be ascertained. The Process approach is learner centered. It exposes learners to a pool of ideas and the teacher as the facilitator or the moderator is always in the position to steer the students towards correction. The Process approach treats all writing as a creative act which requires time and positive feedback to be done well. In process writing, the teacher moves away from being someone who sets students a writing topic and receives the finished product for correction without any intervention in the writing process itself. White and Arndt (1991) say that focusing on language errors 'improves neither grammatical accuracy nor writing fluency'. The changing roles of teacher and students may also be of great assistance in the development of the writing skill. The teacher is to be a facilitator. The teacher needs to move away from being a marker to a reader, responding to the content of student writing more than the form. Students should be encouraged to think about audience: Who is the writing for? What does this reader need to know? Students also need to realize that what they put down on paper can be changed: Things can be deleted, added, restructured, reorganized, adjusted and improved upon.

Finally, the act of composing and generating ideas strengthen originality. Originality berates plagiarism hence the Process Approach which favors the ability to generate ideas may do a lot to sustain academic integrity. 


\section{Implications}

Based on the outcomes of this research work, there appeared to be some observable implications for the following stake-holders.

1. School administrators could see through the Process approach advocated for in this research work that practicing the skill of writing would extend beyond the usual time allotted in the school time table. It might become necessary to find ways of incorporating this in the school time table.

2. Curriculum planners might find it necessary to see how the multi-draft nature of this approach could be planned and made fit into our serialized educational system.

3. Course writers and Task designers would come to the realizations that the learner-centeredness of this approach might call for different orientations and new approach in the planning of the course work as well as designing workable tasks that promote independent writings.

4. The targeting and pursuit of better performance by teachers and students through the adoption of the new approach might pose a serious concern to the textbook publishers. There might be the need to publish new course books and encourage the writing of books that employ the Process approach in the writing skill development.

6. Finally, the classroom teachers could see the issue of knowledge updating as a necessity in the bid to achieving the desirable goals.

\section{Recommendations}

The following recommendations were drawn with respect to this study.

(1) English as second language teachers should adopt this approach for improved performances.

(2) University lecturers who train secondary school teachers should help the secondary school teachers on how to use the Process Approach in writing classrooms.

(3) Publishers should publish books where authors employ the process approach for the teaching of writing.

(4) Curriculum designers should incorporate process activities and teaching auxiliaries in their work.

(5) Enough time should be given to the writing classroom practices to enable students to participate well.

(6) Government should help in procuring books, journals and other facilities that can help in the development of the writing skill.

(7) The Process approach may be of assistance to Language teachers in over-bloated classes.

\section{References}

Adegbile J. A. (1996). Competence in Written English: A Review of Studies by Two Scholars. In Ayodele S. 0. (Ed), Biannual Review of Education Studies. Ibadan the Education Research and Studies Group Institute of Education University of Ibadan.

Akindele F., \& Adegbite W. (2005). The Sociology and Politics of English in Nigeria. Ife. O. A. U. Press.

AboderinA, O. (1986). An Investigation into the Methodological Approaches to Composition Instruction In Ondo State. Teachers' Grade 11 Colleges. Journal of English Studies Nigeria. Akure.

Akinwamide, T. K. (2003). Unpublished Med Thesis Submitted to University of Ado Ekiti, Ekiti State.

Akinwamide, T. K. (2005). Effects of Guided Method of Teaching Essay Writing On the Performance of Students in Nigeria Elementary Secondary Schools. Journal of Education, Vol. 4, No 1. University of Ado Ekiti, Nigeria.

Akinwamide, T. K. (2007). The Basics Approaches to the Teaching of Writing. In Oyinloye G 0 (Ed), Language and Literature Teaching Methods. Matori Lagos, Bifocal Publishers.

Aldana, A. (2005). The Process of Writing a Text by Using Cooperative Learning. Universidad Nacional de Colombia.

Anthony B. (2005). Process Writing and Communicative-Task Based Instruction: Many Common Features but More Common Limitations? University of Seville.

Ayodele, S. O. (1988). The problem of a language for educating Nigerian learners. A Faculty Lecture at the Faculty of Education. University of Ibadan.

Bander, R. (1971). American English Rhetoric: Writing from Spoken Models for Bilingual Students. New York Harper and Row. 
Baskoff F. (1990). New World's: A Course in Guided Composition. Cambridge University Press London.

Baugh \& Cable. (1978). A History of English Language. Third (Ed.). London Routledge and Kegan Paul.OISE.

Burton, A. (2005). Task-based Language Teaching: For the State Secondary F.L Classroom? Language Learning Journal. USA.

Bell J., \& B. Burnaby. (1984). A Handbook for ESL Literacy. Toronto: 3, 55-68

Caudery, T. (1995). What the "Process Approach" Means to Practising Teachers of Second Language Writing Skills. Teaching English as a Second or Foreign Language, Vol. 1, No. 4

D'Angelo, J. D. Frank. (1981). The Search for Intelligent Structures in the Teaching of Composition Tate G and Edward, RJ Corbert (Eds.), The Writing Teacher's Source Book. New York: Oxford University Press.

Duncan, D. (1986). Teaching Competition to large classes: English Teaching Forum, 24(3), 2-5 \&10. USA, States Educational Press.

Ekpa, A. A. (1990). Writing Skills: Towards an improved teaching of essay writing to junior Secondary students. In S. O. Unoh (Ed), Developing English language skills in secondary and higher education. Enugu: Harris publishers Ltd.

Elbow, P. (1981). Writing with power. New York: Oxford University Press. Cambridge, Cambridge University Press.

Flower, L., \& Hayes, J. (1980). A Cognitive Process Teaching of Writing: College Composition and Communication. Cambridge, Cambridge University Press.

Gbenedio, U. B. (1996). Teaching and Learning English as a Second Language. Benin City. New Era Publications.

Ghani S. A. (1986). Group Writing: A Technique That Fosters Creativity. English Teaching Forum. USA, States Educational Press.

Graves, D. (1983). Writing: Teachers and Children at Work. Exeter, Heinemann.

Grill and Proet. (1986). The Process Approach In Action. National Council of Teachers of English. U.S.A.

Gori and Bohu. (1983). Students Perception of Practices in Composition Instruction In Grades 3, 4, S, and 6. In Selected Schools in Western Pennsylvania. An Unpublished PhD Thesis of Pittsburgh.

Hahn C. (1986). Writing at the Early Stages of Language Learning. English Teaching Forum. USA/States Educational Press.

Hubbard R. L. (2003). Communication Skills. Effective Education Publishing 11755 Riverview Drive. St. Louis/Missouri 63138 USA.

Kaplan. R. (1996). Cultural Thought Patterns in International Education Language Learning. USA.

Kharma N. (1986). Composition Problems; Diagnosis and Remedy. English Teaching Forum. USA, States Educational Press.

Krashen S., \& T. Terrell. (1983). The Natural Approach. Oxford: Pergamum Press.

Meriwether, N.W. (1997). Strategies for writing Successful Essay. London, NTC Publishing.

Montague Nicole. (1995). The Process Oriented Approach to Teaching Writing to Second Language Learners. New York State Association for Bilingual Education Journal, V10, pp. 13-24

Murray, D. (1972). Teach writing as a process not product. In Graves, R. (Ed), Rhetoric and Composition; A source for teachers and writers (pp. 89-92). Upper Montclair, NJ: BoyntonjCook.

Myles J. (2002). Second Language Writing and Research: The writing Process And error analysis in students/texts TESL -E1, 6(2), 1-20. Ibadan. Ibadan University Press.

National Examinations Council. (2006). Regulations and Syllabuses for Senior Certificate Examination. Minna, Niger State. Nigeria.

Nunan, D. (1994). Designing Task for the Communicative Classroom. Cambridge, Cambridge University Press.

Obemeata. (1995). Education: An unprofitable Industry in Nigeria. Postgraduate School Interdisciplinary Research Discourse. Ibadan. University Press.

Ogunseye B. (1986). The Use of English in University and other Higher Educational Institutions. In S.O. Unoh (Ed), Use of English in Communication the Nigerian Experience. Ibadan: Spectrum Books Ltd.

Okedara C. A., \& Odeh S. N. (2002). Trends in the Teaching of Composition at the Tertiary Level: The Process 
Writing Approach. Ibadan, Stirling-Horden Publishers.

Oluikpe B. O. A. (1979). Teaching the Art of Writing. In E. Ubahakwe (Ed), The Teaching of English Studies. Ibadan, University Press.

Oluwadiya A. (1992). Some Prewriting Techniques for Student Writers. English Teaching Forum. USA, States Educational Press.

Omojuwa R. A. (2007). General insight into Writing Approaches. (Lecture-Note). A. A. U. Nigeria.

Pica, T. (1986). An International Approach to the teaching of writing. English Teaching Forum. USA, States Educational Press.

Proett J., \& K. Gill. (1986). The Writing Process in Action. A Handbook for Teachers. Illinois: National Council of Teachers of English.

Raimes, A. (1983). Techniques in Teaching Writing. New York: Oxford University Press.

Stevens. (1987). English as an International Language. English Teaching Forum. USA, States Educational Press.

Susser, B. (1994). Process Approach in ESL/EFL Writing Instruction. Journal of Second Language Writing, 3, 31-47. http://dx.doi.org/10.1016/1060-3743(94)90004-3

Vanessa, S. (2004). A Product and Process Writing: A Comparison. London, British Council Educational Service.

White R. (1981). Approaches to Writing Guidelines, 6, 1-11. London, Longman Publishers.

White, L., \& Arndt, V. (1991). Process Writing. Harlow, Essex: Longman.

Table 1. The t-test analysis on the pre-test scores of the Control and Experimental groups for all the variables

\begin{tabular}{|c|c|c|c|c|c|c|c|}
\hline Variables & Groups & $\mathrm{N}$ & $\bar{x}$ & SD & $\mathrm{d} \mathrm{f}$ & t-cal & $\begin{array}{l}\text { t- } \\
\text { table }\end{array}$ \\
\hline \multirow[b]{2}{*}{ Content } & Control & 40 & 1.43 & 0.74 & \multirow[b]{2}{*}{78} & \multirow[b]{2}{*}{0.130} & \multirow{8}{*}{1.980} \\
\hline & Experimental & 40 & 1.40 & 0.96 & & & \\
\hline \multirow[b]{2}{*}{ Organization } & Control & 40 & 1.68 & 0.76 & & \multirow[b]{2}{*}{0.653} & \\
\hline & Experiment & 40 & 1.58 & 0.59 & & & \\
\hline \multirow[t]{2}{*}{ Expression } & Control & 40 & 2.45 & 1.04 & & \multirow{3}{*}{0.206} & \\
\hline & Experimental & 40 & 2.50 & 1.13 & & & \\
\hline \multirow[t]{2}{*}{ Mechanic/Acc } & Control & 40 & 1.43 & 0.84 & & & \\
\hline & Experimental & 40 & 1.45 & 0.78 & & 037 & \\
\hline
\end{tabular}

$\mathrm{P}>0.05, \mathrm{~N}=80 \mathrm{df}=78$

Table 1 above shows that $t$-cal $(0.130,0.653,0206,0.137)$ was less than t-table $(1.980)$ in each of the variables at 0.05 level of significance. The mean scores of the Control group bear no significant difference with the mean scores of the Experimental group. Therefore, the null hypothesis was accepted. That is, there was no significant difference between the pre-test scores of students in both control and experimental groups. This established the homogeneity of the two groups.

Table 2. The t-test analysis on the post-test scores of the Control and Experimental groups

\begin{tabular}{|c|c|c|c|c|c|c|}
\hline Variables & Group & $\mathrm{N}$ & $\bar{X}$ & SD & $\mathrm{tcal}$ & t-table \\
\hline \multirow[b]{2}{*}{ Content } & Control & 40 & 1.43 & 1.01 & \multirow[b]{2}{*}{19.136} & \multirow{8}{*}{1.98} \\
\hline & Experimental & 40 & 5.63 & 0.95 & & \\
\hline \multirow[b]{2}{*}{ Organization } & Control & 40 & 1.53 & 0.95 & \multirow[b]{2}{*}{18.405} & \\
\hline & Experimental & 4.98 & 4.98 & 1.05 & & \\
\hline \multirow[b]{2}{*}{ Expression } & Control & 40 & 2.63 & 1.15 & \multirow[b]{2}{*}{16.659} & \\
\hline & Experimental & 40 & 9.78 & 2.51 & & \\
\hline \multirow{2}{*}{$\begin{array}{l}\text { Mechanical - } \\
\text { accuracy }\end{array}$} & Control & 40 & 1.28 & 0.70 & 11.659 & \\
\hline & Experimental & 40 & 4.05 & 1.33 & 11.659 & \\
\hline
\end{tabular}

$\mathrm{P}<0.05, \mathrm{~N}=80, \mathrm{df}=78$

In the table above, the values of $t$-calculated in each of the variables was greater than the t-table value at 0.05 level 
of significance. Therefore, there was significant difference between the Post-test scores of the experimental and the control groups; hence, the null hypothesis was rejected. The mean scores of the Experimental group are greater than the mean scores of the control group in all the variables. For example, the mean score for Content relevance for experimental group is 5.63 as against that of the Control which is 1.43 . The implication of this is that, the Experimental group has better performance in all the variables than the Control group. This can be traced to the positive effect of the treatment given to the Experimental group.

Table 3. The t-test analysis of the Post-test scores on the overall performance of the Control and Experimental groups in all the variables

\begin{tabular}{|l|l|l|l|l|l|l|}
\hline Group & $\mathrm{N}$ & \multicolumn{1}{|c|}{$\mathrm{X}$} & $\mathrm{SD}$ & $\mathrm{df}$ & t-cal & t-table \\
\hline Control & 40 & 6.85 & 1.211 & \multirow{2}{*}{78} & \multirow{2}{*}{35.499} & \multirow{2}{*}{1.980} \\
\hline Experimental & 40 & 10.0 & 1.35 & & & \\
\hline
\end{tabular}

$\mathrm{P}<0.05, \mathrm{~N}=80, \mathrm{df}=78$

The above table 3 shows that t-calculated (35.499) is greater that the t-table (1.980) at 0.05 level of significance. Therefore, the null hypothesis was rejected. The mean score (10.0) for total performance of the Experimental group is greater than the mean score (6.85) of the Control group, this implied that treatment had significant effect on overall performance in essay writing. The Experimental group performance is better than that of the Control group.

Table 4. The t-test analysis of the pre-test and post - test scores of the Experimental Group

\begin{tabular}{|c|c|c|c|c|c|}
\hline Variable & Test -Type & $\overline{\mathrm{X}}$ & $\mathrm{SD}$ & t-cal & t- table \\
\hline \multirow[b]{2}{*}{ Content } & Pre-test & 1.40 & 0.96 & \multirow[b]{2}{*}{23.252} & \multirow{8}{*}{2.024} \\
\hline & Post-test & 5.63 & 0.95 & & \\
\hline \multirow[b]{2}{*}{ Organization } & Pre-test & 1.58 & 0.59 & \multirow[b]{2}{*}{18.010} & \\
\hline & Post-test & 4.98 & 1.05 & & \\
\hline \multirow[b]{2}{*}{ Experimental } & Pre-test & 2.50 & 1.13 & \multirow[b]{2}{*}{16.114} & \\
\hline & Post-test & 9.78 & 2.51 & & \\
\hline \multirow[b]{2}{*}{ Mech./Accuracy } & Pre-test & 1.45 & 0.78 & \multirow[b]{2}{*}{13.472} & \\
\hline & Post-test & 4.05 & 1.33 & & \\
\hline
\end{tabular}

$\mathrm{P}<0.05, \mathrm{df}=39 \mathrm{~N}=40, \mathrm{t}$-table $=2.024$

Table 4 shows that $\mathrm{t}$-calculated in each of the variables $(23.252,18.010,16.114$ and 13.472) is greater than t-table (2.024); hence the null hypothesis was rejected. This implies that there was significant difference between the pre-test and post scores of the students in the experimental group. The implication of this is that, the performance of the Experimental group after treatment changed for better and the change was significant.

Table 5. The t-test analysis on the pre-test and post-test scores of the students in the Control group

\begin{tabular}{|c|c|c|c|c|c|c|c|}
\hline Variable & Test- Type & $\bar{x}$ & SD & t-cal & t-table & $\mathrm{df}$ & $\mathrm{N}$ \\
\hline \multirow{2}{*}{ Content } & Pre-test & 1.43 & 0.75 & 0.000 & \multirow{8}{*}{2.021} & \multirow{8}{*}{39} & \multirow{8}{*}{40} \\
\hline & Post-test & 1.43 & 1.01 & & & & \\
\hline \multirow[b]{2}{*}{ Organization } & Pre-test & 1.68 & 0.76 & \multirow[b]{2}{*}{1.062} & & & \\
\hline & Post-test & 1.53 & 0.55 & & & & \\
\hline \multirow{2}{*}{ Experimental } & Pre-test & 2.45 & 1.04 & \multirow[b]{2}{*}{0.746} & & & \\
\hline & Post-test & 2.63 & 1.15 & & & & \\
\hline \multirow[b]{2}{*}{ Mech./Accuracy } & Pre-test & 1.43 & 0.84 & \multirow[b]{2}{*}{1.138} & & & \\
\hline & Post-test & 1.28 & 0.70 & & & & \\
\hline
\end{tabular}

$\mathrm{P}>0.05$

In the table above, the mean difference between pre-test and post-test scores in each of the variables is not significant. The table also shows t-calculated less than t-table at 0.05 level of significance; hence, the hypothesis was accepted. The implication of the above is that the students in the control group had no significant improvement in 
the pre-test and post-test. No matter how long an inappropriate approach is employed, desirable results will be elusive.

\section{Appendix 1}

Figure 1. A model of the Process Approach (Akinwamide, T. K 2012)

$$
\text { CONTENT AND CONCEPT ORGANISATION }
$$

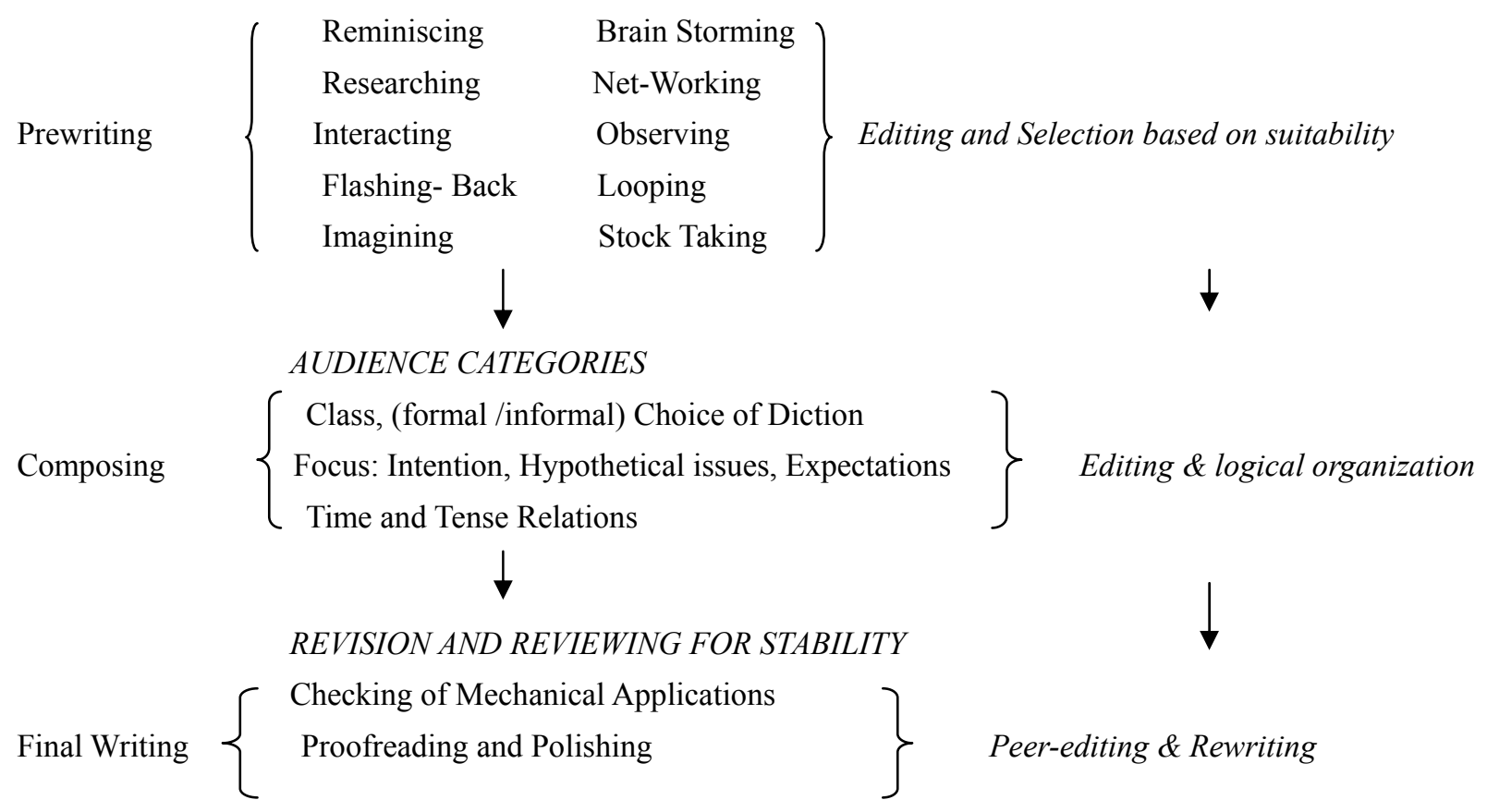

\section{Appendix 2}

ESSAY WRITING ACHIEVEMENT TEXT (EWAT) (50 marks)

\section{INSTRUCTIONS}

You are required to attempt only one question from this section.

Your answer should be about 450 words long. All the questions carry equal marks.

1. Write a vivid description of any cultural festival in your village/town.

2. Write a story that illustrates the wisdom of the saying: A rolling stone gathers no moss.

3. Write a letter to the Chairman of the Election Petition tribunal insisting on cancellation of the results of the recently conducted Local Government Chairmanship election in your area and why you are of that view.

4. Write an article on the topic: Examination malpractice and what Government can do to curb it. 


\section{Appendix 3}

\section{Scoring Procedure}

The researcher employed the WAEC and NECO analytical method of grading essay.

VARIABLES

Content

Organization

Expression

Mechanical Accuracy

TOTAL

\section{Appendix 4}

Diagram of the Design

\begin{tabular}{|l|l|l|l|}
\hline Group & Pre-test & Treatment & Post-test \\
\hline Experiment & O1 & X & O2 \\
\hline Control & O3 & & O4 \\
\hline
\end{tabular}

Where $0_{1}$ means first observation for experimental group.

$\mathrm{O}_{3}$ means first observation for control group.

$\mathrm{X}$ means treatment for experimental group.

$\mathrm{O}_{2}$ means second observation for experimental group.

$\mathrm{O}_{4}$ means second observation for control group 